\title{
Spore Germination in Onygena equina, Willd.
}

\author{
BY \\ WILLIAM B. BRIERLEY \\ (Late Lecturer in Economic Botany, Manchester University), Laboratory of \\ Plant Pathology, Royal Botanic Gardens, Kew.
}

$O^{\prime}$ $N Y G E N A E Q U I N A$, Willd., is a somewhat rare ascomycetous fungus occurring on decomposing horns and hoofs of cattle, sheep, horses, \&c. The fructifications are globular and stalked, pseudo-parenchymatous in texture, and dehisce irregularly. The asci are very evanescent and the spores when ripe fill the peridium as a loose powdery brown mass mixed with 'capillitium fibres'. During the growth of the sporocarp abundant chlamydospores are developed, which form a peripheral crust enclosing the dome-shaped mass of the young fructification.

Prior to Marshall Ward's investigations ${ }^{1}$ the conditions of ascospore germination were unknown, although of the related species, $O$. corvina, de Bary $^{2}$ had made the significant observation that the spores refused to grow in water or nutrient solutions, or in gastric juice, at any temperature, "but there was a fine formation of compound sporophores of Onygena on the hairs cast up by a white owl . . . which had received the spores of the fungus with a mouse which it had eaten. The fungus developed on the hair from the mouse on which the spores had been strewed and from no other.' Ward also found that ascospores placed directly in water or various nutrient media refused to germinate, but, following the clue given by de Bary's observation, caused their germination by subjecting them to a preliminary digestion in artificial gastric juice. De Bary had tried this method using extract of pig's stomach, and his failure must be attributed to some accessory circumstance.

Marshall Ward found that the chlamydospores also germinated readily after digestion with gastric juice, but later discovered that, in certain nutrient media, their germination was possible in the absence of such treatment, although apparently considerably promoted by it.

On January 2, 1914, a large ram's horn bearing sporocarps of Onygeria

1 H. Marshall Ward : Onygena equina, Willd., a Horn-destroying Fungas. Phil. Trans, Roy. Soc., B, vol. cxci, pp. 269-9I, I899.

A. de Bary: Comp. Morph, and Biol. of the Fangi, etc., p. $351,1887$.

[Annals of Botany, Vol. XXXI. No. CXXI. January, 1917.] 


\section{28 Brierley.-Spore Germination in Onygena equina, Willd.}

equira, Willd., was found on the heather moorlands of the Peak District. This was left exposed on the roof of the botanical laboratory at Manchester University, and during the following two years continually produced fructifications of the fungus. ${ }^{1}$

Germination of ascospores. By carefully breaking open a mature ascocarp, pure sowings of the ripe spores may easily be obtained. These were placed in hanging drops of various strengths of nutrient media and kept at different temperatures, but the negative results only confirmed the experience of previous investigators. A preliminary treatment of the spores with artificial gastric juice, ${ }^{2}$ or an admixture of this with the nutrient media, readily produced abundant germination after about five or six days at room temperature $\left(16^{\circ}-18^{\circ} \mathrm{C}\right.$.) or three to five days in an incubator at $23^{\circ} \mathrm{C}$. The nutrient media were those commonly employed in the laboratory, including various plant extracts, peptone, beer wort, \&c. Germination occurred in all; but good subsequent growth was only obtained in a few of those of animal origin, such as peptone and blood fibrin and the more special media described below.

By accident, however, it was discovered that, given a sufficiently long resting period, direct germination may occur in the complete absence of any digestive treatment. Towards the end of January, the exact date being unknown, a number of mature fructifications were picked off the horn and placed in a tin box. This was lost sight of and only rediscovered when the room was turned out for its summer vacation cleaning. The sporocarps were again left lying in the box on a shelf, and it was only on September ${ }_{3} 3$ that the idea occurred to me that possibly the direct germination of the spores might be conditioned by a resting period. Hanging drops of water, ${ }^{3}$ gelatine, ${ }^{4}$ and coarse glue ${ }^{5}$ were immediately prepared, undigested spores from the dried and shrivelled fructifications sown, and the cells left at room temperature. On September 17 abundant germination was noted in the glue and gelatine and a vigorous growth resulted. On September 20 a few abnormal germ tubes, often dilated (Keimblasen), were noted from the spores

1 The original intention was to make a detailed investigation into the development and physiological relations of Onygena, bat as it now appears very improbable that opportunity will permit of this, the present fragment bes been thought perhaps worthy of separate pablication.

- Made according to the formola given by Marshall Ward, and consisting of roo c.c. of $0.4 \% \mathrm{HCl}(\mathrm{I} \cdot 3$ c.c. of commercial $\mathrm{HCl}$ in 100 c.c. $\mathrm{H}, \mathrm{O})$ added to $0.2 \mathrm{grm}$ pepsine dissolved in 100 c.c. $\mathrm{H}, \mathrm{O}$.

Sterilized tap-water.

- I00 grm. of gelatine in I,000 c.c. of water. Filtered and sterilized in Koch steamer on three successive days.

s Fine or pale-coloured glues are usually treated with antiseptics. The coarse glue used was a very dark coloured impure substance in lumps broken out from a large solidified mass. It possessed a strong unpleasant smell and rapidly decomposed, and was obtained for me by a dealer, who described it as 'first boiling'. Twenty-five grammes of this glue were added to one litre of water and heated until it dissolved. It was then filtered and sterilized in a Koch steamer on three successive dajs. 
in water, but here no further growth was obtained. Hanging drops of cowdung extract, ${ }^{1}$ glue, gelatine, and water were then prepared, fresh mature spores were sown, and the cells were left at room temperature and in the incubator at $23^{\circ} \mathrm{C}$. These cells were carefully preserved and when necessary the medium was renewed. From September 18 until February 2 no change was observed, but on the latter date the contents of many of the spores in the dung extract in the incubator appeared to become slightly clearer. On February 8 germination was noted, and two days later this was fairly abundant, about 40 per cent. of the spores putting out germ tubes. In the glue germination occurred on February II, in the gelatine on February I9, whilst no germination occurred in the hanging drops of water. The spores which had been kept at room temperature germinated about the same time, but more irregularly. In this case also no germination occurred in water. The minimum resting period under these conditions was therefore 143 days.

On February 2, 1915, sowings were again made of spores from the original specimens in the tin box, which had thus been in a state of desiccation for twelve months. On February I 4 germination occurred in cow-dung extract, on February 16 in glue, and the following day in hanging drops of gelatine. No germination occurred in water. In the nutrient media only about 20 to 25 per cent. of the spores germinated.

On August 15, 1915, hanging drops containing spores from the original material, after eighteen months' desiccation, were again prepared, but no germination could be obtained.

The ripe ascospores are brown in colour with a slightly thickened wall, and if their formation be carefully traced it will be noted that this thickening and coloration occur subsequent to the attainment of their full dimensions. In the unripe condition they are clear and hyaline, and usually lying free within the peridium. By therefore carefully splitting away the peripheral chlamydospore crust of a nearly mature fructification and breaking open the latter, almost pure sowings of the full-grown but unripe spores may be obtained. On March 5, I9I4, such spores were placed in hanging drops of cow-dung extract, glue, gelatine, and water, and the cells left at room temperature, $23^{\circ} \mathrm{C}$. and $37^{\circ} \mathrm{C}$. No germination occurred at the latter temperature, but on March 8 vigorous growths began from about 70 per cent. of the spores at $23^{\circ} \mathrm{C}$. and on March 9 from those at room temperature. In water many of the germ tubes were abnormal, and growth ceased after about the third day. These spores had received no preliminary treatment of any kind.

The observations so far described would appear therefore to show :-

(a) That the resistance which the mature ascospores offer to direct and immediate germination is correlated with changes in the thickening and coloration of the spore wall.

$150 \mathrm{grm}$. of air-dried fresh cow-dung well shaken in $\mathrm{r}, 000$ c.c. tap-water, filtered and beated in Koch steamer on three successive days. 


\section{I30 Brierley.-Spore Germination in Onygena equina, Willd.}

(b) That the ripe ascospores will germinate after a resting period in the absence of digestive treatment.

(c) That digestive treatment with artificial gastric juice eliminates or greatly curtails this resting period.

Influence of low temperature on ascospore germination. Following the successful lead given by Eriksson, ${ }^{1}$ with spores of the Uredineae, Marshall Ward tried to bring about the germination of the ascospores of Onygena by first subjecting them to a temperature below zero. In only one case was any germination observed, and Marshall Ward ${ }^{2}$ himself terms this case 'doubtful', and suggests ' that the successful germination without gastric juice was really that of the chlamydospores'. In my own observations this method was given a very thorough trial. Freezing mixtures, melting ice, and exposure out of doors to frost were used, and with the spores in situ in the fructifications, freshly removed as a loose powder, suspended in water, and air-dried from water suspensions upon glass slides. Not one case of germination was observed, and it would seem that the method of forcing the germination of spores by , subjecting them to low temperatures is inapplicable to the spores of Onygena equina.

Germination of the chlamydospores. The media in which Marshall Ward obtained the germination of chlamydospores in the absence of preliminary digèstive treatment were hydrolized horn, and cow-dung and gelatine plus hydrolysed horn; these being maintained at a temperature of $22^{\circ}$ to $23^{\circ} \mathrm{C}$. In the first case the spores were fresh and germinated well. In the second the spores had been soaked in water for two hours at $35^{\circ} \mathrm{C}$. before sowing and the germination was very poor.

In the present investigation hanging drops containing spores were prepared on March 17. Germination occurred on March 23, about 60 per cent. of the spores in hydrolysed horn ${ }^{3}$ putting out germ tubes and about 50 per cent. of those in dung extract and gelatine plus hydrolysed horn (equal quantities of dung extract and hydrolysed hom plus io per cent. gelatine). In addition, hanging drops of Witte's peptone, ${ }^{4}$ glue, water, gelatine, and cow-dung extract had been prepared, and, with the exception of the spores in water, abundant germination ( $5 \circ$ to 70 per cent.) occurred after five or six days. In water only a few germ tubes were protruded, and many of these were abnormal and gave no further growth. Chlamydospores treated with gastric juice before sowing possessed no advantage over those lacking

1 Eriksson, J.: Uber die Förderung der Pilzsporenkeimang durch Kälte. Centralb. f. Bakt., Abt. a, Bd. i, No. I5/16, pp. 557-65, 1895 .

2 Marshall Ward, loc. cit., pp. 277, 279.

' 10 grm. of shavings from fresh ram's horn were' dissolved in 100 c.c. of boiling $20 \%$ pure concentrated sulphoric acid. This was neutralized with barium carbonate, filtered, and sterilized in the antoclave.

4. I00 c.c. distilled water, I grm. peptone, I grm. sodium chloride, heated and then filtered. Sterilized in Koch steamer on three successive days. 
such treatment. It would appear, therefore, that Marshall Ward's partial failure in obtaining germination must be set down to some accessory factor.

Some general conditions affecting spore germination. It may be of interest to record a few observations on the more general factors conditioning the germination of spores of Onygena equina.

It is well known that treatment with certain acids markedly stimulates the germination of particular fungus spores, ${ }^{1}$ and it seemed therefore of interest to ascertain whether the immediate germination of ascospores of Onygena after treatment with artificial gastric juice is to be attributed to the digestive action of the latter, or whether it is merely due to the stimulative effect of the hydrochloric acid.

Accordingly observations were made on parallel series of experiments with spores treated in several ways. In the first series the spores were immersed in various strengths of pepsine solution $;^{2}$ in the second in various strengths of hydrochloric acid $;^{3}$ and in the third in artificial gastric juice. As a check three other series were arranged, in one of which the spores were immersed in water, and in the remaining two in various strengths of acetic acid and of lactic acid." After varying periods of time ${ }^{5}$ spores from each series were transferred to Van Tieghem cells containing hanging drops of glue, and placed in a dark cupboard at room temperature. The results were very striking in that only those ascospores which had been treated with gastric juice germinated; and there can be no doubt therefore that the digestive action of this fluid is directly responsible for the stimulation of the spores to immediate development.

Full-grown unripe ascospores when immersed in gastric juice at a temperature of $23^{\circ} \mathrm{C}$. for three hours germinated normally. Six hours' digestion reduced their germinative capacity by about 15 per cent. and produced many abnormal germ tubes, whilst twelve hours' immersion almost completely inhibited germination. Ripe ascospores were rendered incapable of germination by digestion for twenty-four hours at $23^{\circ} \mathrm{C}$., and their germinative capacity greatly reduced by fifteen hours' immersion, these results being approximately true for the chlamydospores also.

The effect of a low temperature is well marked. In situ in the closed fructification the spores are able to withstand repeated freezings, and lost no power of germination when frozen in a solid block of ice on three successive nights. If, however, the spores are in a state of suspension in water or airdried from such a suspension on a glass slide, they are markedly less resistant, and after fifteen hours' exposure to a temperature below zero or remaining for that period of time frozen in ice, all power of germination is lost. The chlamydospores are slightly more resistant than the ascospores,

1 See B. M. Duggar: Physiological Stadies with reference to the Germination of certein Fangus Spores. Bot. Gaz., vol. xxxi, Pp. 38-66, Jan. 1901.

$20.1 \%, 0.2 \%, 0.4 \%, 0.8 \%, 1.0 \%, 3.0 \%$. $0.2 \%, 0.4 \%, 0.6 \%, 0.8 \%, 1.0 \%, 3.0 \%$

- Series as HCL

s I hr., 3 hrs, 6 hrs, 9 hrs, 15 hrs., 24 hrs.

K 2 


\section{Brierley.-Spore Germination in Onygena equina, Willd.}

whilst the full-grown but unripe ascospores are appreciably less resistant than the mature spores. It is worthy of note that ripe ascospores and chlamydospores which have been exposed to a freezing temperature for five hours, and then treated with gastric juice at $23^{\circ} \mathrm{C}$. for a similar length of time, retain almost undiminished their germinative capacity. If the reverse treatment be adopted and the spores are first digested and then frozen they become incapable of germination.

Ascospores are highly resistant to desiccation, and, as already noted, will germinate after twelve months' drying in situ at room temperature. If air-dried from a water suspension on cover slips and kept at $23^{\circ} \mathrm{C}$., they are still viable after a period of seven weeks; at $37^{\circ} \mathrm{C}$., after three weeks, but not after four weeks; and at $54^{\circ} \mathrm{C}$., not after two hours. Spores air-dried upon human hair or cotton-wool from a suspension in water, and maintained at $23^{\circ} \mathrm{C}$, had lost no power of germination after nine weeks; and at $37^{\circ} \mathrm{C}$. still showed abundant germination at the end of a similar period. Spores which had germinated and were then dried out on the cover-slip at any temperature proved incapable of further growth.

No appreciable difference is to be noted in the germination of spores occurring in darkness or the diffuse light of the laboratory.

\section{SUMmaRY.}

The ripe ascospores of Onygena equina will germinate directly after a prolonged resting period, which may be curtailed or eliminated by a preliminary treatment of the spores with artificial gastric juice, but not by subjection to low temperatures.

The full-grown unripe ascospores and the chlamydospores will germinate immediately in the absence of digestive treatment. 